\title{
梶山 喜一郎
}

\section{1. 自分の頭で考える}

自分の頭でものを考えるとうことは，とんでもなく大 変で, 悠長で, 効率の悪いことである。橋本治によると, 自分で考えると, 当然のことながら, 孤独というものが やってくる。この心細い自分をなんとかしてもらいたい ということになる。自分の頭で結論を出すぐらいの我慢 をすればいいとの発想はなく，だれか何とかしてほしい とすぐ救済を求めてしまう。結論を受け売りする授業で すらそうである。

授業で突然私から質問を受けた学生の気持ちはこの様 なものであろう。うつむいた学生達のいる教室の雲囲気 は, 教師の私を孤独にさせる。教師も, 学生が結論をだ すまで待つことができなくなる。教師は, 学生の代わり に答え, 早くこの場を収拾し次のテーマに進みたくなる。 教師の答えにより, 教室の緊張は解け学生達は, また板 書を黙々と写し始める。私語もせず講義に集中している 学生の状態を見て，私は教師として満足する。このよう な学校では, 教材についての模範的知識や正しい解答を 述べることが教師の主な仕事となる。

\section{CAI で活気のある授業}

この 10 年多くのCAI授業が行われた。CAIを用いた授 業は学生にうけが良かった。この方式の授業は, 学生に とって内容が理解しやすくゲーム性もあり楽しいとの評 価がある。演習の正解率もあがっている。操作の質問も 授業を活発に見せる。先ほど述べたクラスと違い, 学生 は積極的に授業に参加しているように見える。教師も学 生も授業を満足しているようである。では授業で図学教 育の目標は達成できているのだろうか。

\section{3. 図学教育の目標}

図学教育での目標は，簡単なことである。その一つは 幾何学図形で対象を認識することである。ブッカーが言 うように, Wの文字をコピーする際に, 文字の高さと巾, 角度を意識して写すことである。桜の花や松ぼっくりを
見るときに，正五角形や渦巻き曲線の幾何学図形を見る ことである。今流行の自動車を見るときに，どの様な曲 面でボディを構成したかを考えることである。五重の塔 の複雑な姿が，どのような基本図形で構成したかを知ろ うとすることである。教師が授業中に板書した図面や図 形を, 学生は, いつも幾何学図形としてみることである。 これらを実際に実行にすることは学生にとって困難であ る。

\section{4. 教師の教授とCAI}

幾何学的知識は持っているが，幾何学的知識で様々な 対象や現象をみることをしない学生がいる。図学の入門 教育は, 彼らに対象や現象を幾何学的知識でみる習慣を 学習させることである。つまり教室の外で対象の持つ属 性の一つとして幾何学図形を思い起こす，あるいは幾何 学図形の視点で対象に働きかける習慣を持たせることで ある。

(1)教材のリアリティ

授業で用いる立体図形の表現技術は，板書にはじまり， OHP, ビデオ, ワイヤーフレームモデル, サーフェイス モデルのCG，アニメーションCGへと進化した。教師の 多くは，教材で使用する立体図や立体図形の表現がより 実物に近づくこと，つまりリアリティを持つことが，学 生に授業が分かりやすくなると考えている。そうであろ うか。

動物の生と死を分ける本能的行動では親そっくりのあ るいは敵そっくりの視覚的画像で, 敵味方を理解するの ではなかった。H.ティンバーゲンによると，セグロカモ メの雛は, くちばしの先に赤い点あるいは黒い点がある かどうかでえさをくれる親を理解している。

幾何学的図形は, 実物から, 值段や重さ匂いなどの属 性を捨てて, 形状とその大きさを抽象化した物である。図 学はこの抽象化した次元で, 学生に対象や現象を考える 習慣を持つことを勧めている。実物から図形を意識的に 抽象化しょうとしない学生には, 板書の意味不明な図も, 
色彩や陰もある立体図形のCG も同じように見えているの

ではないか。

(2)教師による指導の内容

CAIは，学生に何を教授しているのか。どの様にして 幾何学図形を思い起こす習慣を持たせようとしているの か。まず教師が行なう実長実角の問題や相貫体の問題の 授業の進行を観察してみる。A教師は立体図を用い教材の 立体図形を説明する。この説明の過程で，A教師は教室で 学生に対しどの様な指導をしているのか。

$\mathrm{A}$ 教師は立体図形を説明しながら, 学生が立体図を, 説 明している立体図形として想像しているか反応をみてい る。学生が立体図をそのように見ないならば，立体図と 立体図形の関係の説明が必要になる。教材に沿って, 立 体図形の持つ角度・辺の長さ, 図形の大小, 図面と実形 の関係を説明する。学生が想像した立体図形のなかで, 教 材のステップを追うごとに説明する図形が理解されたか 反応をみる。学生が図形を理解できなければ, 彼らに図 形の形状や大きさを考える準備を促す。さらに図形の大 小を見きわめるためには, 彼らに直角, 平行, 合同, 相 似の幾何学的知識を図形に使用する準備を促す。学生が 幾何学的知識を持たなければ，その説明が必要になる。

学生の理解に応じた A 教師のこの様な働きかけが無い 限りは，学生は教室でただ図形や図面を見聞きしている だけである。授業の時間は消費しているが, A 教師と学生 の間で授業は成り立っていない。A教師と学生の間で質問 のやり取りをしなければ, 学生の理解は A 教師に伝わら ないし， A 教師の考えていることも伝わらない。

CAIの授業で，学生自身がこのような内容をやらなけ ればならないとしたら, 指導は行われていない。CAIは 黙々と黒板を写す授業と変わらないだろう。授業は立体 図形・教科書・演習問題・正解だけでは成立しない。教 育には, 教師と学生の間の instructionが必要である。CAI は, 教材のコンピュータ化でなく, コンピュータによる instructionの理想を追い求めたものである。今後の図学の CAI は，もっと図学教師に近づかねばならないであろう。

かじやまきいちろう 福岡大学工学部 